\title{
Control some foodborne pathogens, contaminated bacteria and fungi by fabrication calyx cape gooseberry (Physalis peruviana L.) nanoparticles
}

\author{
Hany Mohamed YEHIA ${ }^{1,2 *}$ (D), Manal Fawzy ELKHADRAGY ${ }^{3}$, Rania Ibrahim SHEBL ${ }^{4}$, \\ Abdulrahman Hamad Al-MASOUD ${ }^{1}$, Mohamed Ferkry Serag EL-DIN ${ }^{1,5}$
}

\begin{abstract}
We studied the effect of the calyx of cape gooseberry nanoparticles manufactured by a novel technique. There are several methods, such as jet mill, spray freezing, supercritical anti-solvent technique (SAS), and high-pressure homogenization, available for the production of drug micro/nanoparticles to improve drug solubility. Anti-solvent precipitation is also used to prepare micro- and nanosized particles to explain their effects on different foodborne pathogens, contaminated bacteria, and some fungi. Results indicated that nanoparticles of the cape gooseberry calyx contained higher antioxidant activity than that found in the normal calyx, seed, and juice. While studying the effect of cape gooseberry calyx nanoparticles on microorganisms, it was found that the zone of inhibition was highly positive against Bacillus cereus, B. subtilis, Staphylococcus aureus, Clostridium perfringens, and Salmonella typhimurium compared to that of the normal cape gooseberry calyx. All species of molds, including Mucor sp., Aspergillus niger, Penicillium sp., and Alternaria sp., and yeasts like Saccharomyces cerevisiae and Rhodotorula glutinis were affected by nanoparticles of the cape gooseberry calyx compared to those of the normal calyx.
\end{abstract}

Keywords: calyx; cape gooseberry; nanoparticles; antioxidant activities; microorganisms.

Practical Application: Calyx Cape Gooseberry (Physalis peruviana L.) Nanoparticles can be used as antangonistic effect against foodborne pathogenic bacteria.

\section{Introduction}

The cape gooseberry (Physalis peruviana L.) is an annual plant belonging to the family Solanaceae, and it is a short-lived perennial that can grow up to one meter (Ramadan, 2011). It contains vitamins $\mathrm{A}$ and $\mathrm{C}$, some of the vitamin B-complexes, and minerals, such as phosphorus, iron, potassium, and zinc Salazar et al., 2008). The nutritional composition and bioactive components found in gooseberries confirm its main benefits (Hassanien, 2001). Fruit juices are complex and heterogeneous colloidal insoluble particles dispersed in a continuous medium rich in soluble compounds, including sugars, organic acids, soluble pectins, phenolic compounds, and salts (Eraso-Grisales et al., 2021). Antioxidant contents and high levels of vitamin $\mathrm{E}$ of gooseberry have considerable functional properties (Ramadan \& Moersel, 2009). Phenolic compounds of gooseberry have been extensively studied for their health properties from the epidemiological point of view, and their functionality depends on their content, intake, and bioavailability. Bioavailability of these compounds can also be affected by microstructure and binding of phenolic compounds within the food matrix, which are directly related to fruit processing (Balasundram et al., 2006).

The calyx of cape gooseberry contains five hairy sepals and veins and has a length of about $4-5 \mathrm{~cm}$ after fecundation that completely cover the fruit during development and growth (Flórez et al., 2000). At the beginning through 40-45 d of development, it appears green. However, after fruit ripening, it loses chlorophyll and turns yellow-orange. At this stage, it can protect the fruits from birds, insects, extreme climate conditions (including cold, heat, and hail), and mechanical damage as well as serve as an indispensable source of carbohydrates for the first $20 \mathrm{~d}$ of fruit growth (Fischer et al., 2000).

In the inner base of the calyx, a glandular tissue that produced a terpenic resin when the fruit had a diameter of $10-11 \mathrm{~mm}$, which covers the fruit up to its mature stage (Baumann \& Meier, 1993). This researcher believed that the resin could be a repellent against insects. Further, some substances, such as withanolide $\mathrm{E}$ and $4 \mathrm{~B}$-hydroxywithanolide, have been found to increase surrounding the calyx in contact with the fruit, and during maturation, at a concentration that leads to an anti-feeding effect (Franco et al., 2007). Currently, the market requires the commercialization of fruit without calyx, which reduces the shelf life of the fruits (Cárdenas-Barboza et al., 2021). Although Olivares-Tenorio et al. (2017) mentioned that under storage conditions at $12{ }^{\circ} \mathrm{C}$ cape gooseberry with calyx has a shelf life of 24 days, and fruits without calyx only retain

${ }^{1}$ Food Science and Nutrition, College of Food and Agriculture Science, King Saud University, Riyadh, Saudi Arabia

${ }^{2}$ Food Science and Nutrition, Faculty of Home Economics, Helwan University, Cairo, Egypt

${ }^{3}$ Zoology Department, Faculty of Science, King Saud University, Riyadh, Saudi Arabia

${ }^{4}$ Department of Microbiology and Immunology, Faculty of Pharmacy, Ahram Canadian University - ACU, Cairo, Egypt

${ }^{5}$ Department of Nutrition and Food Science, Faculty of Home Economics, Minufiya University, Minufiya, Egypt

*Corresponding author: hanyehia@ksu.edu.sa 
their quality postharvest for 11 days. So there are necessary to manufacture of calyx nanoparticle for using these leaves in the production of components has benefits to human.

Nanoparticle compounds research is a new heavily investigated area due to their potential in improving the properties of materials. Combination between high-antioxidant materials and nanoparticles is a new branch of inquiry to help scientists control the growth and distribution of microorganisms.

Therefore, the aim of this study was to manufacture nanoparticles of cape gooseberry calyx with dimensions of less than $100 \mathrm{~nm}$ using the new nanonization (reduction in size) method to control or limit the growth of known microorganisms distributed in nature and to study their antioxidant activity.

\section{Materials and methods}

\subsection{Sample preparation}

The fruits of $P$. peruviana L. were purchased from a local market in Riyadh city, Saudi Arabia. The calyx was separated from the fruits, cut into small pieces, and dried in a dry oven at $60^{\circ} \mathrm{C}$. The dried leaves were soaked in methanol $(100 \mathrm{mg} / \mathrm{mL})$ and left overnight in a refrigerator. The mixture was then centrifuged at $5000 \mathrm{rpm}$ for $5 \mathrm{~min}$. The supernatant was used directly and tested against microorganisms. The fruits were blended, and the seeds and juice were separated using a small sieve.

\subsection{Fabrication of calyx cape gooseberry nanoparticles}

Calyx cape gooseberry powder $(300 \mathrm{mg})$ was added to $20 \mathrm{~mL}$ of methanol while stirring. Following, under ultrasonic conditions, this solution was sprayed into boiling water $(40 \mathrm{~mL})$ in a dropwise manner at a flow rate of $0.2 \mathrm{~mL} / \mathrm{min}$ in $5 \mathrm{~min}$ using an ultrasonic power of $750 \mathrm{~W}$ and a frequency of $20 \mathrm{kHz}$. After sonication for $10 \mathrm{~min}$, the contents were stirred at 200-800 rpm at room temperature $\left(20^{\circ} \mathrm{C}\right)$ for approximately $20 \mathrm{~min}$. The solution was dried to obtain Calyx Cape Gooseberry as nanoparticles.

\subsection{Antioxidant activities}

\section{Total phenolic compounds}

Total content of phenolic compounds in methanolic extracts was determined by the Folin-Ciocalteu method as described by Wu et al., 2007, briefly, $2.5 \mathrm{~mL}$ of distilled water and $0.1 \mathrm{~mL}$ of sample extract were added to a test tube, followed by addition of $0.1 \mathrm{~mL}$ of undiluted commercially available Folin-Ciocalteu reagent (Sigma-Aldrich, St. Louis, MO, USA). The solution was mixed well and allowed to stand for $6 \mathrm{~min}$ before $0.5 \mathrm{~mL}$ of a $20 \%$ sodium carbonate solution was added. The color was allowed to develop for $30 \mathrm{~min}$ at room temperature, and the absorbance was measured at $760 \mathrm{~nm}$ using a spectrophotometer (Milton Roy Spectronic 1201, USA). A blank sample was prepared using $0.1 \mathrm{~mL}$ of methanol instead of extract. The measurement was compared to a calibration curve of gallic acid solutions and expressed as gallic acid equivalents per gram of dry weight sample.

\section{Total flavonoids content}

The total flavonoid content of crude extract was determined by the aluminum chloride colorimetric method according to Baba \& Malik (2015), In brief, $50 \mu \mathrm{L}$ of crude extract was mixed with $4 \mathrm{~mL}$ of distilled water followed by $0.3 \mathrm{~mL}$ of $5 \%$ $\mathrm{NaNO}_{2}$ solution. Further, $0.3 \mathrm{~mL}$ of $10 \% \mathrm{AlCl}_{3}$ solution was added after 5-min incubation, and the mixture was allowed to stand for $6 \mathrm{~min}$. Subsequently, $2 \mathrm{~mL}$ of $1 \mathrm{~mol} / \mathrm{L} \mathrm{NaOH}$ solution was added, and the final volume of the mixture was brought to $10 \mathrm{~mL}$ with distilled water. The mixture was allowed to stand for $15 \mathrm{~min}$, and the absorbance was measured at $510 \mathrm{~nm}$. The total flavonoid content was calculated from a calibration curve, and the result was expressed as $\mathrm{mg}$ rutin equivalent per $\mathrm{g}$ dry weight or $\mathrm{mg}$ catechin equivalent per $\mathrm{g}$ dry weight.

\section{DPPH (2,2-diphenyl-1-picrylhydrazyl) radical scavenging activity}

The ability of the samples to scavenge DPPH radicals was determined according to the method of Akillioglu and Karakaya, 2010. A $0.08 \mathrm{mM}$ DPPH radical solution in methanol was prepared. Following, $950 \mu \mathrm{L}$ of DPPH stock solution was added to $50 \mu \mathrm{L}$ extract and incubated for $5 \mathrm{~min}$. At precisely $5 \mathrm{~min}$ later, absorbance readings of the mixture were performed at $515 \mathrm{~nm}$ (Cary 50 Scan; Varian). Antioxidant activity (AA) was expressed as percentage inhibition of DPPH radical using the following equation: $\mathrm{AA}=100-\left[100 \times\left(\mathrm{A}_{\text {sample }} / \mathrm{A}_{\text {control }}\right)\right]$, where $\mathrm{A}_{\text {sample }}$ is the absorbance of the sample at $\mathrm{t}=5 \mathrm{~min}$, and $\mathrm{A}_{\text {control }}$ is the absorbance of the control.

\section{ABTS (2, 4, 6-Tri (2-Pyridyl)-s-triazine) radical scavenging activity}

The $\mathrm{ABTS}^{++}$assay was performed according to the method of Gouveia and Castilho, 2011. The ABTS ${ }^{++}$radical solution was prepared by reacting $50 \mathrm{~mL}$ of $2 \mathrm{mM}$ ABTS solution with $200 \mu \mathrm{L}$ of $70 \mathrm{mM}$ potassium persulfate solution. This mixture was stored in the dark for $16 \mathrm{~h}$ at room temperature, and it remained stable in this form for two days. For each analysis, the $\mathrm{ABTS}^{++}$solution was diluted with $\mathrm{pH} 7.4$ phosphate buffered saline (PBS) solution to an initial absorbance of $0.700 \pm 0.021$ at $734 \mathrm{~nm}$. This solution was freshly prepared for each set of analyses. To determine the antiradical scavenging activity, an aliquot of $100 \mu \mathrm{L}$ methanolic solution was added to $1.8 \mathrm{~mL}$ of $\mathrm{ABTS}^{++}$solution, and the absorbance decrease, at $734 \mathrm{~nm}$, was recorded during $6 \mathrm{~min}$. Results were expressed as $\mu \mathrm{mol}$ Trolox equivalent per g of dried sample (mmol eq. Trolox/g), based on the Trolox calibration curve.

\section{Ferric reducing antioxidant power (FRAP)}

Ferric reducing antioxidant power (FRAP) was performed according to the procedure described by Benzie \& Strain, 1996. The FRAP reagent included $300 \mathrm{mM}$ acetate buffer, $\mathrm{pH}$ 3.6, $10 \mathrm{mM} \mathrm{TPTZ}$ in $40 \mathrm{mM} \mathrm{HCl}$, and $20 \mathrm{mM} \mathrm{FeCl}_{3}$ at the ratio 10:1:1 (v/v/v). Briefly, $3 \mathrm{~mL}$ of the FRAP reagent was mixed with $100 \mu \mathrm{L}$ of the sample extract in a test tube and vortexed in a $37^{\circ} \mathrm{C}$ incubator for $30 \mathrm{~min}$ in a water bath. Reduction of ferrictripyridyltriazine to the ferrous complex formed an intense blue 
color, which was measured using a UV-vis spectrophotometer (Varian Cary 50) at $593 \mathrm{~nm}$ at the end of $4 \mathrm{~min}$. Results were expressed in terms of mmol Trolox equivalent per $\mathrm{g}$ of dried sample (mmol eq. Trolox/g).

\subsection{Antimicrobial assays}

\section{Test microorganisms}

The following microorganisms were tested: Bacillus cereus ATCC 14579, Salmonella typhimurium ATCC 14028, Listeria monocytogenes ATCC 19114, Bacillus subtilis (local isolate), Staphylococcus aureus ATCC 29737, Clostridium perfringens ATCC 13124, Escherichia coli ATCC 10537, Micrococcus luteus (local isolate), Saccharomyces cerevisiae DSMZ 1333, Rhodotorula glutinis (local isolate), Mucor sp. (local isolate), Aspergillus niger (local isolate), Penicillium sp. (local isolate), and Alternaria sp. (local isolate).

\section{Agar well diffusion method}

Agar diffusion method was used to determine the antimicrobial activity of Calyx Cape Gooseberry nanoparticles against some foodborne pathogens, contaminated bacteria, and fungi, which are listed above. Briefly, $100 \mu \mathrm{L}-10^{6} / \mathrm{mL}$ of each active bacterial strain, which were grown on Brain Heart Infusion agar (Oxoid $\mathrm{CM} 1136$ ) for $24 \mathrm{~h}$ at $37^{\circ} \mathrm{C}$, were spread on the surface of Muller
Hinton agar plates (Oxoid CM 0337). Further, $50 \mu \mathrm{g} / \mathrm{mL}$ of cape gooseberry calyx nanoparticles and normal calyx were dissolved in methanol and left overnight in a refrigerator. Subsequently, three holes using a 6-mm diameter sterile cork borer were punched on the agar. One hole contained a volume of $100 \mu \mathrm{L}$ of cape gooseberry calyx nanoparticles, second contained $100 \mu \mathrm{L}$ of normal cape gooseberry calyx, and the third contained only $100 \mu \mathrm{L}$ methanol as a control. Finally, the agar plates were incubated at $37^{\circ} \mathrm{C}$ for $24 \mathrm{~h}$, and the effects of calyx cape gooseberry nanoparticles and normal calyx (measured as zone of inhibition) were recorded as positive and negative results.

\section{Results and discussion}

Figure 1 shows the morphology of the resulting nanoparticles as investigated by transmission electron microscopy (TEM). TEM images revealed that a thin layer of organic material surrounded the nanoparticles, which is indicative of the cape gooseberry calyx. Furthermore, the resulting calyx cape gooseberry nanoparticles had irregular spherical shapes due to aggregation.

The size of the synthesized nanoparticles was analyzed through Zetasizer (Figure 2). The average particle sizes (diameter) varied from about $1 \mathrm{~nm}$ to $261 \mathrm{~nm}$, and the Polydispersity Index (PDI) was 0.3 , which represents mono-dispersity as observed clearly from the peak indicating particle stability.

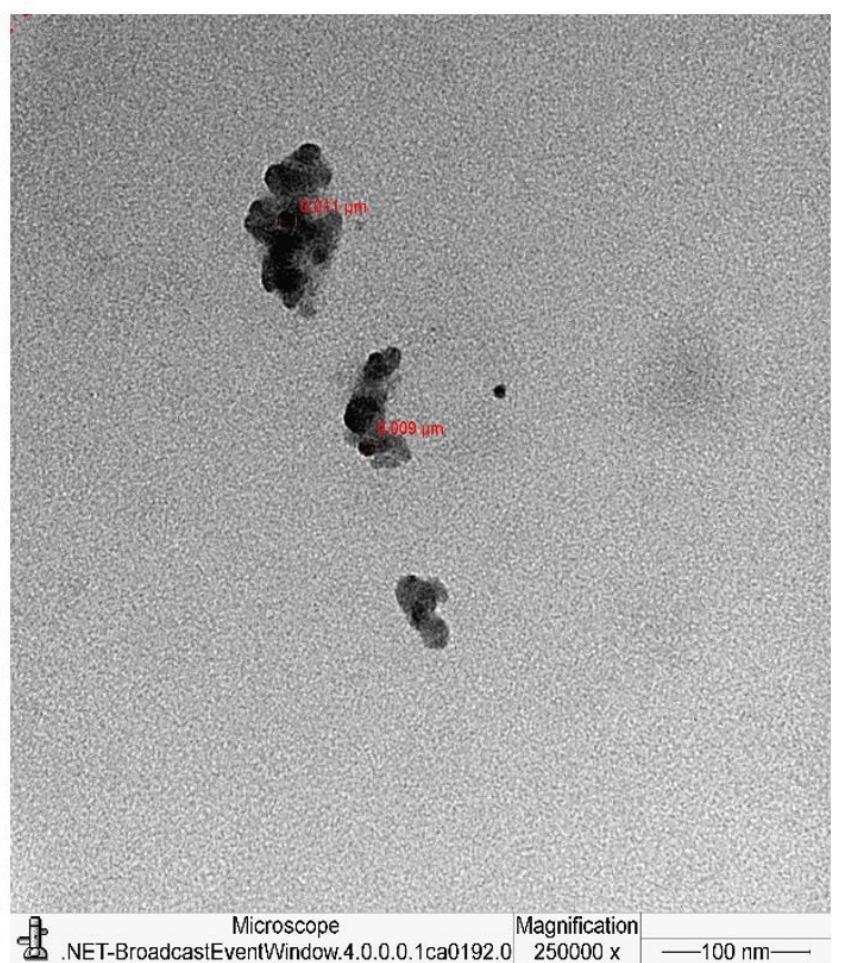

A

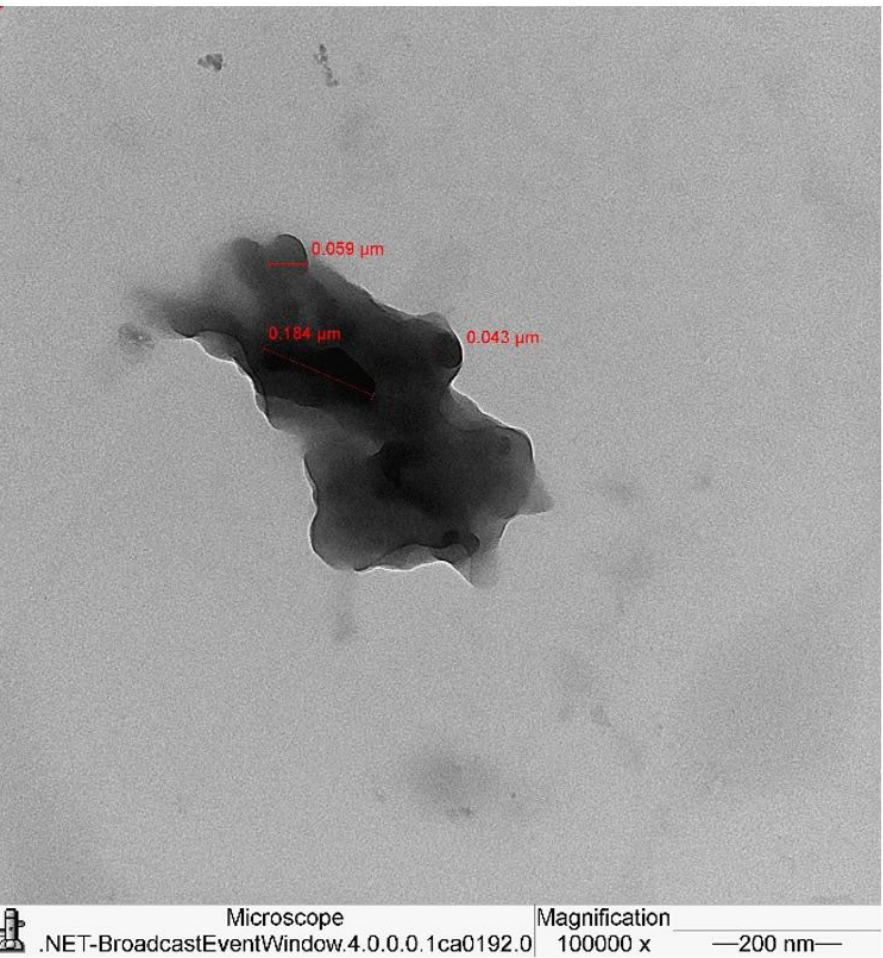

Figure 1. Transmission electron microscopy $($ TEM). Microphotograph of calyx cape gooseberry synthesized nanoparticles at $10000 \times(\mathrm{A})$ and $250000 \times$ (B) magnifications. 
Data in Table 1 show the total phenols in normal calyx of cape gooseberry at $42.385 \pm 0.402 \mathrm{mg}$ gallic acid/g sample. This quantity was higher than found in both bulbs and seeds, which were $4.547 \pm 0.080$ and $3.350 \pm 0.160$, respectively. Further, total flavonoids of normal calyx of cape gooseberry, determined as $\mathrm{mg}$ catachin and rutin/g sample, were $2.058 \pm 0.149$ and $19.196 \pm 1.648$, respectively, but were not detected in both bulbs and seeds. Similar antioxidant activity of flavonoids freeradical scavenging agents (DPPH and ABTS) of normal calyx of cape gooseberry was $32.75 \pm 0.289 \%$ and $0.8601 \pm 0.0095 \mathrm{~g}$ (g trolox/g sample). In contrast, DPPH found in bulbs and seeds was $21.72 \pm 0.328$ and $16.48 \pm 0.289 \%$, and ABTS was $0.2105 \pm 0.0022$ and $0.1521 \pm 0.0015 \mathrm{~g}$ (Trolox/g sample), respectively. Ferric reducing antioxidant power (FRAP) found in normal calyx of cape gooseberry was $0.5373 \pm 0.0126 \mathrm{~g}$ (Trolox/g sample). For bulbs and seeds, values were $0.0764 \pm 0.0037$ and $0.0498 \pm 0.0020 \mathrm{~g}$ (Trolox/g sample), respectively. From the above data, it is evident that normal calyx of cape gooseberry contained higher antioxidant capacity than found in bulbs and seeds. As a result, we selected the calyx to prepare nanoparticles, and the results showed that its antioxidant capacity increased 2 -fold compared to normal calyx for total phenols, DPPH, ABTS, and FRAB, which were $85.088 \pm 4.093$ (mg Gallic acid $/ \mathrm{g}$ sample), $69.517 \pm 1.131 \%, 1.667 \pm 0.012$ (g Trolox/g sample), and $1.604 \pm 0.180$ (g Trolox/g sample), respectively. For verification that the effect of calyx nanoparticles not due to antioxidants alone after nantechnique method, the nanoparticles frees filtration was

$\begin{array}{rllll} & & \text { Size (d.nm): } & \text { \% Intensity: } & \text { St Dev (d.nm): } \\ \text { Z-Average (d.nm): } 261.4 & \text { Peak 1: } & 152.1 & 100.0 & 35.38 \\ \text { Pdl: } 0.302 & \text { Peak 2: } & 0.000 & 0.0 & 0.000 \\ \text { Intercept: } 0.779 & \text { Peak 3: } & 0.000 & 0.0 & 0.000\end{array}$

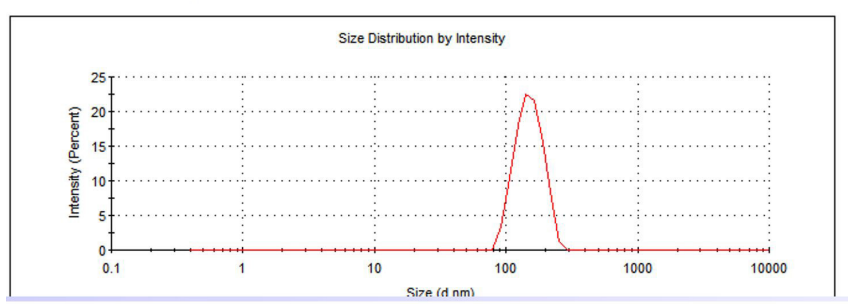

Figure 2. Zetasizer analysis. Measurement of formed Calyx cape gooseberry nanoparticles size by zetasizer. tested against microorganisms. The same inhibition zone was noticed against microorganisms. The calyx's cape gooseberry, a material that encloses the fruit, protecting it from insects, birds, diseases, and adverse weather conditions, is considered as a post-harvest waste. However, infusions of this material are used in traditional medicine to reduce the symptoms of arthritis (Wei et al., 2012; Simbaqueba et al., 2011; Wu et al., 2005; Yen et al., 2010). In previous studies, an important antioxidant and anti-inflammatory activity was obtained from leaves and stems of this species, associated with the presence of flavonoids and other compounds with antioxidant properties (Wu et al., 2005; Fischer et al., 2000; Hassanien \& Moersel, 2003; Wu et al., 2006). Some authors studies the effect of extracts of cape gooseberry and appeared a protective effect in liver and inhibit cancer cell lines growing and showed anti-inflammatory activity (Puente et al., 2011; Al-Olayan et al., 2014; Çakir et al., 2014).

Therefore, nanoparticles of the calyx of cape gooseberry for activity against some foodborne pathogens, contaminated bacteria, molds, and yeasts, as shown in Table 2 found that almost all bacterial strains, molds, and yeasts were affected by calyx nanoparticle compared to the normal calyx due to its high antioxidant activity.

Many studies reported the contents of cape gooseberry and its biological activities in extracts of fruits, stems, leaves, and calyx. Folk medicine of most organs of cape gooseberry, including leaves, stems, and roots, have been widely used because of their diuretic, antiseptic, antifungal, antibacterial, anti-carcinogenic, antimalarial and anti-inflammatory effects (Puente et al., 2011; Wu et al., 2007; Akillioglu \& Karakaya, 2010) Some authors have studied the effect of extracts of cape gooseberry and have shown a protective effect in the liver, growth inhibition in cancer cell lines, and anti-inflammatory activity (Gouveia \& Castilho, 2011; Benzie \& Strain, 1996).

The anti-inflammatory activity of leaf and plant stem extracts from Physalis peruviana has been confirmed mainly in macrophages (Benzie \& Strain, 1996). Another study of Physalis peruviana ethanol extracts from leaves and shoots-external material is not edible and provides separate protection of the fruit also known as the calyx-showed antibacterial activity, antioxidant activity, and protection against DNA damage by controlling the expression of $\mathrm{Bcl}-2$ family genes, which regulate apoptosis in HeLa (Tapia \& Fries, 2007). Regarding the study

Table 1. Content of total phenols, flavonoids and antioxidant activity of flavonoids free-radical scavenging (DPPH and ABTS) and ferric reducing antioxidant power (FRAP) found in the bulb, seed and calyx of cape gooseberry (Physalis peruviana).

\begin{tabular}{lcccccc}
\hline Cape gooseberry & $\begin{array}{c}\text { T. Phenols (mg } \\
\text { Gallic acid /g } \\
\text { sample) }\end{array}$ & $\begin{array}{c}\text { T. Flavonoids } \\
(\mathbf{m g} \text { Catachin /g } \\
\text { sample) }\end{array}$ & $\begin{array}{c}\text { T. Flavonoids } \\
\text { (mg Rutin/g } \\
\text { sample) }\end{array}$ & DPPH (\%) & $\begin{array}{c}\text { ABTS (g } \\
\text { Trolox/g sample) }\end{array}$ & $\begin{array}{c}\text { FRAB (g } \\
\text { Trolox/g sample) }\end{array}$ \\
\cline { 2 - 7 } & $\mathrm{M} \pm \mathrm{SD}$ & $\mathrm{M} \pm \mathrm{SD}$ & $\mathrm{M} \pm \mathrm{SD}$ & $\mathrm{M} \pm \mathrm{SD}$ & $\mathrm{M} \pm \mathrm{SD}$ & $\mathrm{M} \pm \mathrm{SD}$ \\
\hline Normal & & & & & & \\
Cape gooseberry calyx & $42.385 \pm 0.402$ & $2.058 \pm 0.149$ & $19.196 \pm 1.648$ & $32.75 \pm 0.289$ & $0.8601 \pm 0.0095$ & $0.5373 \pm 0.0126$ \\
Cape gooseberry bulbs & $4.547 \pm 0.080$ & $\mathrm{ND}$ & $\mathrm{ND}$ & $21.72 \pm 0.328$ & $0.2105 \pm 0.0022$ & $0.0764 \pm 0.0037$ \\
Cape gooseberry seeds & $3.350 \pm 0.160$ & $\mathrm{ND}$ & $\mathrm{ND}$ & $16.48 \pm 0.289$ & $0.1521 \pm 0.0015$ & $0.0498 \pm 0.0020$ \\
Nanoparticle & & & & & & \\
Cape gooseberry calyx & $85.088 \pm 4.093$ & $0.377 \pm 0.024$ & $0.609 \pm 0.264$ & $69.517 \pm 1.131$ & $1.667 \pm 0.012$ & $1.604 \pm 0.180$ \\
\hline
\end{tabular}


Table 2. Comparison between effect of methanolic extract of calyx of cape gooseberry nanoparticles and normal calyx on Gram positive, negative bacterial strains, molds, and yeasts.

\begin{tabular}{|c|c|c|c|}
\hline \multirow[b]{2}{*}{ Extractions Microorganisms } & \multirow[b]{2}{*}{${ }^{*} \mathrm{G}+/ \mathrm{G}-/ \mathrm{Y} / \mathrm{M}$} & \multicolumn{2}{|c|}{ Methanolic extraction } \\
\hline & & $\begin{array}{l}\text { Normal calyx of cape } \\
\text { gooseberry }(100 \mu \mathrm{L})\end{array}$ & $\begin{array}{c}\text { Nanoparticle calyx of cape } \\
\text { gooseberry }(100 \mu \mathrm{L})\end{array}$ \\
\hline B. cereus ATCC 14579 & $\mathrm{G}+$ & + & +++ \\
\hline S. typhimurium ATCC 14028 & G- & + & ++ \\
\hline L. monocytogenes ATCC 19115 & G+ & - & ++ \\
\hline B. subtilis (local isolate) & $\mathrm{G}+$ & + & +++ \\
\hline Clostridium perfringens ATCC13124 & G+ & + & +++ \\
\hline E. coli ATCC 10537 & G- & - & ++ \\
\hline Staph. aureus ATCC 29737 & G+ & + & +++ \\
\hline Mucor sp. (local isolate) & $\mathrm{M}$ & + & +++ \\
\hline Aspergillus niger (local isolate) & M & + & +++ \\
\hline Penicillium sp.(local isolate) & M & + & +++ \\
\hline Alternaria sp.(local isolate) & M & + & +++ \\
\hline Rhodotorula glutinis (local isolate) & $\mathrm{Y}$ & + & ++ \\
\hline Saccharomyces cerevisiae DSMZ 1333 & $\mathrm{Y}$ & + & +++ \\
\hline Micrococcus luteus (local isolate) & $\mathrm{G}+$ & + & +++ \\
\hline
\end{tabular}

"G+: Gram positive bacteria; G-: Gram negative bacteria; Y: Yeast; M: Mold.

of the calyces of cape gooseberry, there are a few reports on the effect of normal calyx; however, no studies are related to the effect of nanoparticles on microorganisms.

\section{Conclusions}

Regarding the study of the calyces of cape gooseberry, few studies have been conducted on the normal calyx and none related to nanoparticles. We can conclude that the methanolic extract of the calyx of cape gooseberry nanoparticles demonstrated good action potential against some Gram-positive and negative bacteria, most molds, and yeasts compared to the normal calyx. The effect of calyx cape gooseberry nanoparticles is due to its high antioxidant capacity, suggesting that it could play an important role in antimicrobial activity and be applied in different fields.

\section{Conflict of interest}

The authors declare no conflict of interest.

\section{Acknowledgements}

The authors would like to extend their sincere appreciation to the Deanship of Scientific Research at King Saud University for funding of this research through the Research Group Project no. RG-1435-016.

\section{References}

Akillioglu, H. G., \& Karakaya, S. (2010). Changes in total phenols, total flavonoids, and antioxidant activities of common beans and pinto beans after soaking, cooking, and in vitro digestion process. Food Science and Biotechnology, 19(3), 633-639. http://dx.doi.org/10.1007/ s10068-010-0089-8.

Al-Olayan, E. M., El-Khadragy, M. F., Aref, A. M., Othman, M. S., Kassab, R. B., \& Moneim, A. E. A. (2014). The potential protective effect of Physalis peruviana L. against carbon tetrachloride-induced hepatotoxicity in rats is mediated by suppression of oxidative stress and downregulation of MMP-9 expression. Oxidative Medicine and Cellular Longevity, 2014, 381413. http://dx.doi.org/10.1155/2014/381413. PMid:24876910.

Baba, S. A., \& Malik, S. A. (2015). Determination of total phenolic and flavonoid content, antimicrobial and antioxidant activity of a root extract of Arisaema jacquemontii Blume. Journal of Taibah University for Science, 9(4), 449-454. http://dx.doi.org/10.1016/j. jtusci.2014.11.001.

Balasundram, N., Sundram, K., \& Samman, S. (2006). Phenolic compounds in plants and agri-industrial by-products: antioxidant activity, occurrence, and potential uses. Food Chemistry, 99(1), 191203. http://dx.doi.org/10.1016/j.foodchem.2005.07.042.

Baumann, T. W., \& Meier, C. M. (1993). Chemical defense by withanolids during fruit development in Physalis peruviana. Phytochemistry, 33(2), 317-321. http://dx.doi.org/10.1016/0031-9422(93)85510-X.

Benzie, I. F. F., \& Strain, J. J. (1996). The ferric reducing ability of plasma (FRAP) as a measure of "antioxidant power": the FRAP assay. Analytical Biochemistry, 239(1), 70-76. http://dx.doi.org/10.1006/ abio.1996.0292. PMid:8660627.

Çakir, O. C., Pekmez, M. C., Çepni, E., Candar, B., \& Fidan, K. (2014). Evaluation of biological activities of Physalis peruviana ethanol extracts and expression of Bcl-2 genes in HeLa cells. Food Science and Technology, 34(2), 422-430. http://dx.doi.org/10.1590/fst.2014.0060.

Cárdenas-Barboza, L. C., Paredes-Córdoba, A. C., Serna-Cocka, L., Guancha-Chalapud, M., \& Torres-León, C. (2021). Quality of Physalis peruviana fruits coated with pectin and pectin reinforced with nanocellulose from P. peruviana calyces. Heliyon, 7(9), e07988. http://dx.doi.org/10.1016/j.heliyon.2021.e07988. PMid:34568603.

Eraso-Grisales, S., Cortes-Rodríguez, M., Castaño-Peláez, H. I., \& Hurtado-Benavides, A. (2021). Enzymatic hydrolysis of a colloidal system based on cape gooseberry. Food Science and Technology. Ahead of Print. http://dx.doi.org/10.1590/fst.67820.

Fischer, G., Ebert, G., \& Lüdders, P. (2000). Provitamin A carotenoids, organic acids and ascorbic acid content of cape gooseberry (Physalis peruviana L.) ecotypes grown at two tropical altitudes. Acta Horticulturae, (531), 263-267. http://dx.doi.org/10.17660/ActaHortic.2000.531.43. 
Flórez, V. J., Fischer, G., \& Sora, A. D. (2000). Producción, poscosecha y exportación de la uchuva (Physalis peruviana L.). Bogota: Universidad Nacional de Colombia.

Franco, L. A., Matiz, G. E., Calle, J., Pinzón, R., \& Ospina, L. F. (2007). Actividad antinflamatoria de extractos y fracciones obtenidas de cálices de Physalis peruviana L. Biomédica, 27(1), 110-115. http:// dx.doi.org/10.7705/biomedica.v27i1.237. PMid:17546228.

Gouveia, S., \& Castilho, P. C. (2011). Antioxidant potential of Artemisia argentea L'Hér alcoholic extract and its relation with the phenolic composition. Food Research International, 44(6), 1620-1631. http:// dx.doi.org/10.1016/j.foodres.2011.04.040.

Hassanien, M. F. R. (2001). Physalis peruviana: a rich source of bioactive phytochemicals for functional foods and pharmaceuticals. Food Reviews International, 27(3), 259-273. http://dx.doi.org/10.1080/ 87559129.2011.563391.

Hassanien, M. F. R., \& Moersel, J. T. (2003). Das physalis beerenoel: eine neuentdeckte quelle an essentiellen fettsaeuren, phytosterolen und antioxidativen vitaminen. Flüssiges Obst, 7, 398-402.

Olivares-Tenorio, M. L., Dekker, M., Van Boekel, M. A. J. S., \& Verkerk, R. (2017). Evaluating the effect of storage conditions on the shelf life of cape gooseberry (Physalis peruviana L.). Lebensmittel-Wissenschaft + Technologie, 80, 523-530. http://dx.doi.org/10.1016/j.lwt.2017.03.027.

Puente, L. A., Pinto-Muñoz, C. A., Castro, E. S., \& Cortés, M. (2011). Physalis peruviana Linnaeus, the multiple properties of a highly functional fruit: a review. Food Research International, 44(7), 17331740. http://dx.doi.org/10.1016/j.foodres.2010.09.034.

Ramadan, M. F. (2011). Bioactive phytochemicals, nutritional value, and functional properties of cape gooseberry (Physalis peruviana): an overview. Food Research International, 44(7), 1830-1836. http:// dx.doi.org/10.1016/j.foodres.2010.12.042.

Ramadan, M. F., \& Moersel, J. T. (2009). Oil extractability from enzymatically-treated goldenberry (Physalis peruviana L.) pomace: range of operational variables. International Journal of Food Science \& Technology, 44(3), 435-444. http://dx.doi.org/10.1111/j.13652621.2006.01511.x.

Salazar, M., Jones, J., Chaves, B., \& Cooman, A. A. (2008). A model for the potential production and dry matter distribution of Cape gooseberry (Physalis peruviana L.). Scientia Horticulturae, 115(2), 142-148. http://dx.doi.org/10.1016/j.scienta.2007.08.015.

Simbaqueba, J., Sanchez, P., Sanchez, E., Zarantes, V. M. N., Chacon, M. I., Barrero, L. S., \& Mariño-Ramírez, L. (2011). Development and characterization of microsatellite markers for the cape gooseberry Physalis peruviana. PLoS One, 6(10), e26719. http://dx.doi.org/10.1371/ journal.pone.0026719. PMid:22039540.

Tapia, M., \& Fries, A. (2007). Guía de campo de los cultivos andinos. Lima: FAO.

Wei, J., Hu, X., Yang, J., \& Yang, W. (2012). Identification of single-copy orthologous genes between Physalis and Solanum lycopersicum and analysis of genetic diversity in Physalis using molecular markers. PLoS One, 7(11), e50164. https://www.ncbi.nlm.nih.gov/pmc/articles/ PMC3500348/pdf/pone.0050164.pdf. http://dx.doi.org/10.1371/ journal.pone.0050164. PMid:23166835.

Wu, C., Murthy, H. N., Hahn, E.., \& Paek, K. (2007). Improved production of caffeic acid derivatives in suspension cultures of Echinacea purpurea by medium replenishment strategy. Archives of Pharmacal Research, 30(8), 945-949. http://dx.doi.org/10.1007/ BF02993961. PMid:17879746.

Wu, S. J., Ng, L. T., Huang, Y. M., Lin, D. L., Wang, S. S., Huang, S. N., \& Lin, C. C. (2005). Antioxidant activities of Physalis peruviana. Biological \& Pharmaceutical Bulletin, 28(6), 963-966. http://dx.doi. org/10.1248/bpb.28.963. PMid:15930727.

Wu, S. J., Tsai, J. Y., Chang, S. P., Lin, D. L., Wang, S. S., Huang, S. N., \& Ng, L. T. (2006). Supercritical carbon dioxide extract exhibits enhanced antioxidant and anti-inflammatory activities of Physalis peruviana. Journal of Ethnopharmacology, 108(3), 407-413. http:// dx.doi.org/10.1016/j.jep.2006.05.027. PMid:16820275.

Yen, C. Y., Chiu, C. C., Chang, F. R., Chen, J. Y., Hwang, C. C., Hseu, Y. C., Yang, H. L., Lee, A. Y., Tsai, M. T., Guo, Z. L., Cheng, Y. S., Liu, Y. C., Lan, Y. H., Chang, Y. C., Ko, Y. C., Chang, H. W., \& Wu, Y. C. (2010). 4 $\beta$-Hydroxywithanolide E from Physalis peruviana [golden berry] inhibits growth of human lung cancer cells through DNA damage, apoptosis and G2/M arrest. BMC Cancer, 10(1), 46. http:// dx.doi.org/10.1186/1471-2407-10-46. PMid:20167063. 